\title{
Article \\ Decoding the elements of human rights from the verses of Ancient Vedic literature and Dhar- maśāstras: An Exegetical Study
}

Authors: Shailendra Kumara Sanghamitra Choudhurybcdef

Department of Management, Sikkim University, India

Department of Asian Studies, St. Antony's College, University of Oxford, Oxford, UK

Department of History and Anthropology, Queen's University, Belfast, Northern Ireland, UK

Hague Academy of International Law, Hague, the Netherlands

Centre for the Study of Law and Governance, Jawaharlal Nehru University, New Delhi, India

Department of Peace and Conflict Studies and Management, Sikkim University, Gangtok, India

\begin{abstract}
This manuscript aims to provide a nuanced study of the idea of rights and duties prevalent in ancient Vedic society through Vedic literature and Dharmaśāstras . This manuscript delves into the exegesis of the Védas and Dharmaśāstras to accomplish this. The archaic Vedic literature and Dharmaśāstra texts are the origin and backbone of Sanskrit literature. They have a plethora of ideas that, if accepted, could be quite useful for the protection of any person's human rights. In Védas and Dharmaśāstras, rights and duties complement each other, and rights are integrated by duties. According to these texts, rights and duties are correlated and the relationship between rights and duties leads to the core concept of dharma (constitutional laws). Dharma is a systematic Sanskrit concept that includes traditions, obligation, morals, laws, order, and justice. It was a unique concept of dharma that kept checks and balances on sovereign officials and prevented them from becoming autocratic and anarchist. It also provided the common man with a protective shield against the dictatorship of sovereign officials. Ordinary citizens had more privileges and fewer responsibilities relative to the state's highest officials. The greater the authority, the less his privileges were, and the more extensive his responsibilities became. This research is an exegetical analysis of ancient Indian Vedic and later Vedic literature and is primarily aimed at deciphering some of the essential ideas of the rights found in these texts, which are akin to contemporary human rights. It endeavours to discern and explain the tenets of human rights obnubilated in the pristine mantras of Antediluvian Vedic and Smrti texts of India. The essay further attempts to add a much needed non-western perspective to the historiography of human rights.
\end{abstract}

Keywords: Dharma; Duties; Hinduism; Human Rights; India; Dharmaśāstras; Vedic literature. 


\section{Introduction}

Sanatana Dharma or modern Hindu philosophy, does not apply to any single faith, but instead to the spectrum of various faiths, including Vaishnavism, which considers Vishnu to be the supreme deity, Shaivism, which considers Shiva to be the supreme deity, and Shaktism, which considers Shakti to be the supreme deity. According to Charles Eliot, Sanatana Dharma or modern Hinduism has not been formed, but it has evolved. It's a forest, not a building (Eliot-2004). Likewise, K. M. Sen points out, "Hinduism is much like a tree that has slowly evolved than a structure that has been built by a great architect at a certain point of time. It incorporates within itself the roots of other civilizations, and the body of Hindu philosophy, therefore, provides as much diversity as the Indian nation itself "(Sen-2005). However, the terms' 'Hindu' and 'Hinduism' are not indigenous to India and have peregrine inchoation (Rosen-2006). Hinduism is more homogeneous to a mode of life or a code of conduct, which regulates a man's work and activities as a member of society and as an individual. There are numerous manuscripts and historical literature associated with Hinduism's various traditions, the most prominent of which are the Vedic Literature and Smriti texts. Quite often, human rights campaigners consider faith as a threat rather than an ally. While faith presents paramount challenges, it also gives the human rights movement optimism for transformation, together with enhanced pellucidity and influence. As Larry Cox indites, it is unfortunate to believe that human rights and religion are always at odds, particularly because universal standards of morality and dignity are the cornerstone of many religious traditions (Cox-2014). Similarly, in the case of human rights and Hinduism, it is often maintained, that it is derisive to human and civil rights, that if the only possible connection among them is one of equipollently extreme dissent, that the structure of the caste system on which Hinduism is predicated leaves little room for equality on which human rights are predicated. However, such a view appears to be so skewed that it is erroneous. This could involve some validity in particular situations, but it does not overshadow the broader fact that Sanatana Dharma is thoroughly welcoming to human rights. According to the Advaita Vedānta theory, the bond of universal brotherhood between all human beings is profoundly engendered, and no laws are necessary for it (Bokil, 2001: 31). Even though no single religion could be declared as the source of human rights, the human liberation movements are mostly religiously inspired (Patel-2005). This manuscript integrates a much-needed nonwestern perspective into the historiography of human rights. This study is an exegetical work of the Indian Vedic literature and the Smriti texts and mainly aims to decipher some of the significant ideas of rights innate in these texts that are close to contemporary modern rights. Due to practical constraints, this research is limited to exploring the tenets of rights inherent in Vedic and Smrti texts and does not include the critical aspects of these texts. The first part of the manuscript fixates on the heritage of Vedic literature and Dharmaśāstra along with literature review, the second part fixates on the interpretation of various rights-related exegesis of the selected texts, and the third and final part of the manuscript includes a conclusion.

\section{Heritage of Vedic Literature}

Historians have verbally expressed that Indian literature influenced even the history of world literature as it spread to far East Asia, 
Central Asia, Greek, and Europe (Winternitz-1975). In this aspect, Vedic literature deserves an outstanding place in the history of world literature. According to Max Muller, "In the history of the world, the Véda fills a gap which no literary work in any other language could fill. It carries us back to times of which we have no records anywhere and gives us the very words of a generation of men of whom otherwise we could from but the vaguest estimate by denotes of conjecture and inferences. As long as man perpetuates to take on interest in the history of his race, and as long as we accumulate in the libraries and museums the relics of former ages, the first place in that long row of books which contain the records of the Aryan branch of mankind, will belong sempiternally to the Rigvéda." (Muller-1968; p-63). Thus, it is conspicuous that Vedic literature plays a consequential role in Indian history.

According to Clayton, the denomination 'Véda' derives from the Sanskrit word ' $V i d$ ' meaning 'to know', an inchoation that can withal be found in the Latin word 'Videre' meaning 'to see' (Clayton-1980:25). Hence, the term Véda means erudition (knowledge). The Vedic Literature is the oldest documentation engendered by mankind and is the root of the early history of the Indo-Aryan race. One of the significant features of the Védas is the claim of 'apauruseyatva'1 which implies that 'no human being' has been responsible for its existence. In other words, the Védas were revealed to the Antediluvian Sages by God himself, and these sagacious men deliberately composed the Védas so that this cognizance could be transmitted from generation to generation. The seers to whom the Vedic hymns were revealed by God were called Mantradrashtas2. Nevertheless, the references to the apauruseyatva of Védas in themselves are minimal, and not especially clear or convincing. It is mostly in later ancillary literature that the apauruseyatva becomes the commencement point of the Vedic exegesis (Dandekar-2000). It is claimed that the Véda was not written down and read, but rather recited and perceived aurally. It was indubitably this that sanctioned the Vedic texts to be maintained in perfect condition. According to Winternitz, the history of Indian literature is nothing but one great chapter, one of the most brilliant and most important chapters in the history of human minds... and the Véda stands at the head of Indian Literature not only because of its age but because only one who has gained an insight into Vedic literature, could ever understand the intellectual and spiritual life and culture of India (Winternitz-1977). The stratum of Vedic literature includes Śruti (texts which have been auricularly discerned and are aeonian and indisputable) and Smriti (texts which are supplementary to Śruti texts and are recollected and have visually perceived many transmutations over time).

The Śruti literature comprises of

i. Védas or Védah : There are four Védas namely RigVéda, indited in accolade of the Vedic Deities; Yajur Véda deals with strategies for conducting Vedic sacrifices; Atharva Véda deals with hymns linked to superstition and medicine, and Sam Véda deals with music. Every of the four Védas is composed of several Shakhas or recensions. Each recension has its Samhitã,

Brahmana, Aranyaka, and Upanișad. The term Samhitã (collection) implicatively insinuates that the time of Samhitã was preceded by a phase of dispersed and unorganized mantras. It should be noted that the Vedic mantras were originally dispersed and unorganized. They 
were then compiled and encoded into four sections that became prevalent as RigVedic Samhitã , Yajur Vedic Samhitã , Sāma Vedic Samhitã , and Atharva Vedic Samhitã .

ii. Brahmanas or Brāhmaṇam : are the prose texts to explicate the hymns of Védas and additionally contain injunctive authorizations to brahmins to perform rituals. Besides mystical understanding, they are often loaded with empirical information, including astronomy and geometry.

iii. Aranyakas: constitute the theory underlying the religious sacrifice in the Védas. Generally, they reflect later components of the Védas, and they are one of the several layers of the Vedic texts. The term Aranyakas is derived from 'Aranya', meaning forests. These texts were mainly designated for hermits who have peregrinate to forests and renounced the world.

iv. Upanișads: are the philosophical texts which are also called Vedānta, i.e. the terminus of the Védas. There was one hundred and eight (108) number of Upanișads.

\section{The Smriti texts comprise of -}

i. Vedāingas: these are six secondary disciplines linked to the analysis of the Védas. (Coward, 2016). The six Vedāngas are Shiksha i.e. Phonetics; Kalpa i.e. Rituals; Jyotish i.e. Astrology; Nirukta i.e. Etymology; Vykarana i.e. Grammar; and Chhanda i.e. Vedic Meter.

ii. Epics: constitute two great poems, namely Ramayana and Mahabhārata that have laid the framework for the popular Indian culture community and are the cornerstone of Hindu philosophy.

iii. Upavédas: relates to applied knowledge. In the Vedic literature, it denotes technology-related subjects. The list of subjects utilized in the Upavédas is Ayurvéda i.e. study of medicine; Dhanurvéda i.e. study of archery and warfare techniques; Gandharvavéda i.e. study of music and dance; and Sthapatyavéda i.e. study of architecture.

iv. Purānas: contain stories about the creation of the world, from conception to death, as well as genealogies of kings, warriors, sages, and gods. Some Purāṇas have cosmological, geographical, and Hindu philosophical connotations. The Purānas are eighteen( 18) in number and have historical significance.

v. Shatdarshan or Upānga : constitute six(6) Schools of Vedic Philosophy namely:-

Samkhya: Samkhya is the oldest philosophy. It was expounded by the sage called 'Kapil.' It is a paradigm of dualistic logic because it accepts two inherent universal truths, i.e. 'Purusha (Spirit)' and 'Prakriti (Nature).' While 'Prakriti is claimed to be the material foundation of this world, made up of three fundamental elements (Gunas), namely Sattva(pure and good elements, Rajas( combination of good and bad elements) and

Tamas,(dark or bad elements). Samkhya stresses the attainment of self-knowledge by concentration and meditation, 'Purusha' posits as the only sentient being, ever-existent, and immaterial. Samkhya believes that it is self-knowledge that contributes to freedom, and not to any external force or power. Samkhya is a metaphysical basis for yoga. 
Yoga: This was expounded by 'Patanjali' and was predicated on a 'logic' system. Yoga is a form of physical and intellectual control. Yoga offers a concrete road to self-realization, while Samkhya stresses the procurement of self-erudition by concentration and meditation. Yoga does not require confide in God, albeit this credence is apperceived as avail in the initial phase of mental concentration and control.

Nyaya Sūtra: It was propounded by a sage named 'Gautama'. This philosophy advocates that the world is real and one should accept things only when they are per reason ( scientific approach).

Vaiśeșika: It was expounded by a sage named 'Kanada'. This focuses on the idea that anything in the universe is a collection of atoms that exist until the substance component has been reduced to its smallest portion.

- Purva Mìmāmssāa (Mìmāmsāa Sūtra): The basic sense of 'Purva Mīmāmsāa' is 'serious analysis or examination' It was expounded by a sage named 'Jaimini.' The philosophy finds Védas to be timeless and unchanging. It maintains that the universe has always existed, so it is without beginning or finish. It describes Dharma as 'virtue,' 'morality,' or 'service'.

- Uttar Mìmāmsāa or Vedānta: It was expounded by 'Badaryana'. The term 'Vedānta' means the culmination of Vedic speculation.

The philosophy verbally expresses that the world is Maya i.e. illusion. Vedānta is monistic, in other words, it verbalizes that there is only one reality, Brahma(Supreme). Vedānta lays accentuation on Brahma Gyan (supreme knowledge), hence relies on the Upanișad part of the Védas. Vedānta has its roots in Samkhya Philosophy. The prominent sub-branches of Vedānta are - Dvaitādvaita or (dualistic non-dualism) of Nimbarka; Advaita or Absolute Monism of GaudĀpada and Adi Shankaracharya; Viśiștādvaita or qualified monism of Nathmuni, and Ramanuja; Dvaita or Dualism of Madhvacharya; śuddhādvaita or pure non-dualism of Vallabhacharya

i. Āgama and Tantras: Āgama is religious arrangements and practical guides to spiritual worship. These texts justify the real worship of the Godhead. There are seventy-seven Āgama, with teachings on (i) jnana (consciousness), (ii) yoga (meditation), (iii) kriya (action), and (iv) charya (performing). The Āgama is split into three sections: Vaishnava, Shaiva, and Shakta. The Vaishnava Āgama exalts Vishnu to the status of God. The Shaiva Āgama exalt Shiva as a God and gave rise to the Shaiva-Siddhant school of thought (principle). In one of Devi's many names, the Shakta Ágama or Tantras glorify God as the Mother of the Earth.

Dharmaśāstras or Righteousness Science: are the collections of rules of life. They are ancient Hindu jurisprudence texts that have had a very significant impact on Indian culture. There are many Dharmashastras, ranging in number from 18 to around 100, each with different and often contradictory viewpoints. Each of these texts has multiple versions and is based on Dharmasūtra texts from the first millennium BC that emerged from Vedic era Kalpa (Vedānga) studies. These texts, written after the Dharmasutras, use metered verse and are much more elaborate in nature than the Dharmasūtras. The following are the texts that have survived from the Dharmaśāstras: 
- Manu Smrti: is the most well-known and earliest metrical work in Hinduism's Dharmastra textual tradition. It was composed by Manu around c. 2nd-3rd century AD.

- Yājñavalkya Smrti: was composed around 4th -5th century AD. Due to its superior vocabulary and degree of complexity, the Yājnavalkya Smrti (fourth to fifth centuries $\mathrm{CE})$ has been dubbed the "best written" and "most cohesive" text of the Dharmastra tradition. As a legal theory book, it has been as popular as Manu Smriti.

- Nārada Smrti was written around the 5th to 6th century A.D and has been dubbed as the "juridical text par excellence" because it is the only Dharmastra text that focuses exclusively on legal issues, ignoring righteous behavior and penance.

- The Viṣnu Smrti was composed much later around the 7th century AD and does not explicitly address the means of understanding dharma, instead it concentrates on the bhakti tradition.

\section{Rights mentioned in Vedic Literature}

Religion has always played a crucial role in the advancement of human rights, particularly in the advancement of human dignity (Harees-2012). This notion is particularly reflected when one seeks to explore the inherent values laid down in the Vedic texts. Human rights defined in Vedic literature tend to be fundamental, unchangeable, and place a greater emphasis on human obligations than on human rights. Some philosophers argue that, like Judaism, Hinduism has no word for "rights" (Pandeya-1986), but there is a Sanskrit word for "fair claims" called "adhikara". The term "adhikara" is similar to the English term 'rights.' However, in Vedic texts, the concept of adhikara is primarily used in conjunction with the term 'duty.' This understanding is based on the fact that rights and duties are correlative, and rights come with duties. We optically discern, ergo, that western human rights are primarily about rights, not obligations. In the case with most religions, the antithesis is true. Furthermore, in Hinduism, obligations come first, not rights (Bilimoria-1993; Carman-1988). Obligations are primary, and rights can be derived from them. The central concept of dharma is derived from the relationship between rights and responsibilities. Dharma is a Sanskrit term that refers to rituals, responsibilities, morality, law, order, and equity. The religious and moral duties known as dharma were supposed to guide everyone in the culture, including the kings. As a result, 'Dharma' was the king of kings. It was akin to a code of conduct that governed everyone's behaviour in society, including the King's. Professor Kane defined dharma as "a term that encompasses man's entire life" (Nanda-1997. p29).

According to Justice M Rama Jois, since dharma regulated the mutual obligations of individuals and societies, it was expected to be safeguarded in the interests of both (Nanda-1997 p31). Based on a preliminary review of Vedic literature, it appears that the idea of human rights was not well-known in ancient India. However, an in-depth examination reveals that some aspects of human rights were rooted and intrinsic in Vedic hymns. The Vedic king ruled as a sovereign, but not as an autocrat. The Council of Ministers' counsel, old customs, popular opinion, and, most importantly, the dharma influenced it. In comparison to the state's highest ascending bodies, the common citizens had more 
rights and fewer responsibilities. To put it another way, the higher one's heritage, the less their rights and the greater their responsibilities. The word raj-dharma (king's duties or civil law) ensures that the King can safeguard everyone. Similarly, āpad-dharma' applies to responsibilities that must be met during a crisis. During a crisis that embodied the king's āpad-dharma, the King was forced to perform certain duties. The subjects' privileges were derived from the kings' responsibilities. Nonetheless, no separate set of distinct and enforceable rights for subjects to be governed fairly or reasonably by the King is discussed (Sharma2004). Other types of Dharma include collective acts (sadharanadharma), family dharma (kula-dharma), conduct based on the performance of duties appropriate to one's class, gender, and stage of life (varnashrama-dharma), and an individual's specific dharma based on the previous three (sva-dharma) (Sherma-2008). According to Srimad Bhagvat Gita, a person should never consider himself to be the cause of the results of his activities, and never be annexed to not doing his duties (Srimad Bhagvat Gita, Chapter II, Verse 47).

Consequently, it can be inferred that though ancient Indian society was more a duty predicated and not a right predicated society, the rights conferred upon an individual were the rights to perform his duties (Kumar-2020). Sāntiparvan of the epic Mahabhārata mainly deals with the topic of raj dharma, or constitutional obligations of the king and regime. The paramountcy affixed to the obligation is withal conspicuous from the shloka indited in Mahabhārata's Adi Parva, which verbalizes that being born as a human, every person owes four debts, namely Pitra-Rin (Debt towards Parents), Dev-Rin (Debt towards the Deities), Rishi-Rin (Obligations towards Teachers/Sages), and MaanavRin (Debt towards humanity). A man may repay his parents by preserving the family's continuity, God by worshipping the Supreme, Teacher by gaining and disseminating wisdom, and humanity by performing social services (Mahabhārata's Adi Parva Adhyaya 120.17-20).

The Mahabhārata encourages the subjects to rebel against an adharmic king (a king who does not obey the dharma) who is tyrannical, extortive, and sinful, and who fails to fulfil his righteous duty to his subjects (Mahabhārata -Anusasana Parva 61.32-33). The fear of anarchy was a powerful motivator for even a weak and oppressive king to stay on the throne. (1959, Basham). According to the Mahabharata, a man should first choose his king, then his wife, and only then amass wealth, because where would wife and property be without a king in the world? (Poona edition of the Mahabhārata, xii 57, 41).

Article 29 of the Universal Declaration of Human Rights (UDHR), which states that the corollary of rights is duties, reflects the idea of rights arising from duties as enshrined in ancient Vedic texts. ${ }^{3}$ Even M.K. Gandhi believed that all rights deserved and protected came from doing one's duty well. As a result, we only have the freedom to live if we fulfil our responsibilities as world people (Moyn-2016).Thus, the very right to live accrues to us only when we do the duty of citizenship of the world (Moyn-2016).

\section{-Secular Ideals of the State and Rule of Law}

George Holyoake, a British scholar, coined the term "secularism." Secularism, according to Holyoake, is not an argument against any religion, but rather a social order that is independent of religion. The Holyoake principle of secularism is close to the ancient Vedic literature's 
principles of government. The word secularism does not apply to atheism in Vedic texts. According to Vedic texts, secularism is more about conducting state affairs in an unbiased manner while considering the welfare of the subjects without discrimination. Following the establishment of a state, the King was given the power to protect the rights of the subjects, which became part of the 'raj-dharma,' or constitutional law. According to Vedic literature, the state's first duty is to protect the rights of its citizens and to treat them all equally, just as a mother does with her children. It was predicted that, just as Mother Earth offers equal support to all living beings, a king would do the same, without bias or discrimination. ${ }^{4}$ The notion of the right to equality and the values of a secular state stem from the King's duty to treat all of his subjects equally and without prejudice. The king was supreme and had the power to enact legislation, but this power was limited to regulatory legislation rather than substantive or constitutional legislation (dharma). According to Brihadaranyak Upanișad, dharma was the king of kings, and dharma, fortified by the mighty king's power, allows the weak to triumph over the powerful. It asserts that the law (dharma) is supreme, and that the law (dharma) combined with the king's mighty strength enables the poor to prevail over the strong. Dharma practice did not imply enforcing Vedic religion and theology, as non-believers in Vedic philosophy and religion had the right to be protected and to practise their faith freely. ( Brihadaranyak Upanișad 1.4.14) The king's right to rule was contingent on him fulfilling his duties, which may result in his kingship being revoked. According to Mahabhärata, if a cruel and unjust king fails to defend his subjects and purloins them in the name of levying taxes, he should be executed as a mad canine.

The legislators of the post-Vedic period drew on Vedic literature while drafting laws to reflect the state's secular ideals, as shown by the texts of Manu Smṛti and Nārada Smṛti. The King was not allowed to break his responsibilities (raj-dharma), so if the dharma was broken, the King would be destroyed. Nārada Smṛti , on the other hand, demands that the King protect Vedic believers, as well as Vedic disbelievers and others. ${ }^{5}$ Närada Smrti holds that the king (State) should not discriminate in according protection to believers in Véda (Naigamas), as well as those who do not believe in Véda (Pashandis) and of others. The protection should be done in the same manner in which he (King) is under an obligation to protect his fort and territory( Nārada Smrti vide Dharmakosha, P-870).

The rules laid down by the lawmakers of the post-Vedic period were not rigid as the Dharmaśāstra often reiterates that the rules may be transmuted or updated for the welfare and aegis of subjects, given to the fact that a code that sustains society at one age may choke society at another age.

\section{-Liberty, Equality and Fraternity}

The world came up with the high ideals of liberty, freedom, and fraternity, during the French revolution (Setzer-2013). These three principles are enshrined in almost every democratic constitution around the world. On December 10, 1948, the United Nations adopted the Universal Declaration of Human Rights, which states that all human beings are born free and equal in dignity and rights. It goes on to say that humans are endowed with reason and conscience, and that they should behave in a brotherly manner against one another. The concept of personal liberty and the right to life is one of the oldest 
kenned concepts to human beings. This is an inherent right that nature has conferred on humans. Man's Natural Liberty is to be free of any superior authority on Earth, and to be ruled solely by the laws of nature, rather than by man's will or legislative ascendancy (Jones1975). The word liberty has both positive and negative connotations. Liberty implies the lack of restraints in a negative sense. In his Essay on Liberty (as quoted in Johari-1989), John Stuart Mill defends negative liberty by stating that "leaving people to themselves is often better than restricting them," and that "all restraints quo restraints are evil" (Johari -1989). T.H. Green is credited with coining the term "liberty" in a positive way. He describes liberty as the ability to do or enjoy something worth doing or enjoying in the presence of others. In his words, "Will! not force is the basis of the state" (Tyler- 1997; 2019). The most important human right is the right to liberty. "Where liberty dwells, there is my country," wrote a famous English poet (Mencken1942).

RigVéda echoes the ideals of liberty, by calling for the liberty of Tan (body), Skridhi (dwelling place), and Jibhasi (life). These liberties may be compared to contemporary rights such as the right to physical liberty, food, and life (RigVéda -8 : 38:12). The ancient Vedic society highly valued the diversity of thoughts, which is evident from the 112th hymn from the 9th book of the RigVéda which means "diverse are the thoughts and actions of the people"( RigVéda 9.112.01).

Similarly, another hymn of RigVéda reads, "May noble thoughts come to us from every quarter, unchanged, unhindered, undefeated in every way; May the deities never digress from us; May our protectors care for us, ceaseless, every day" (RigVéda 1.89.1). Thus, it is evident that ancient Vedic society was very welcoming to novel ideas and thoughts and it was the paramount duty of the state to protect the liberty of its people and enable them to live life with dignity and happiness. The epic tale Mahabhärata also advocates the civil liberty of individuals in the political state. However, the right to liberty was not paramount and came with certain riders. This is quite conspicuous from the post-Vedic literature called Bharat Nāṭyaśāstra which is the oldest surviving book on performing arts. In the final chapter of the Nātyasaāstra (36.33-35), there is an episode wherein Bharata's sons get arrogant with their knowledge of drama and engender a frugal play that ridicules and caricatures prominent seers and saints. Upset by this, the sages cursed the sons of Bharata, but later they concur to mitigate the effect of their imprecation when deities intervene on behalf of Bharata's son. This instructive episode suggests that there is an inhibition to the liberation of expression and that liberation should not be misused in the designation of artistic liberation and liberty.

According to Ronald Dworkin's theory of equality, the philosophy of equality has its origins in religious heritage. The analysis of the Vedic texts gives credibility to Dworkin's claim. RigVéda advocates that all humans are equal and no one is born either superior or inferior. Everyone should strive to progress and apportion the means of happiness collectively (RigVéda, Mandala-5, Sukta-60, Mantra-5 ). The Upanișads expanded on the RigVéda's equality concept by declaring that all humans are not only identically tantamount but also distinct.

Thus, Vedic literature emphasises the dignity and unity of all human beings without prejudice, as well as the need for humans to work together to advance and distribute the means of happiness collectively. The Vedic seers regarded the whole universe as a single body, believing 
that any flaw in one organ would have an effect on the health and safety of the entire human body. All humans were considered to be God's children, and so all were treated equally. In another shloka, RigVéda emphasizes unity even more, calling for oneness in the intent, emotions, and cerebrations of all human beings so that they may live in bliss together.

The philosophy of egalitarianism or equalitarianism is also obvious in the Samjnana Sukta of Atharva Véda, which says, "Everybody has fair access to food and water. The chariot of life's yoke is balanced on everyone's shoulders. All should live in harmony, fortifying one another like the spokes that connect the rim and hub of a chariot wheel." (Atharvavéda-Samjnana Sukta. Courts of India, p-24).

Another cherished principle of the French Revolution is fraternity, or brotherhood. However, the fraternity's definition and description have always been contentious. The theory of fraternity is the least discussed and has the least licit consequentiality of the three ideals of the French Revolution. However, philomaths such as Bhim Rao Ambedkar and Canadian judge Charles Gonthier have argued for the fraternity's supremacy. "Without solidarity, liberation, and liberty will be no deeper than coats of paint," Bhim Rao Ambedkar (as quoted in PUCL$\mathrm{K}$ report-September, 2012) said in his closing dialogue in the Constituent Assembly Debates of India (September 2012 PUCL-K report). Similarly, as Canadian judge Charles Gonthier put it when explaining the importance of fraternity, "liberty and equality depend on the fraternity to flourish" (Gonthier, et al., 2000). Gonthier goes on to say that, in terms of social justice, it is not enough to protect people's right to liberty and self-determination; it is also necessary to protect their ability to flourish by assisting those who need assistance. Liberty and Equality, according to M. Rama Jois, are ideals that can be achieved by constitutional betokens, but fraternities deserve more than constitutional betokens (Rama-2017). For humans to live a joyful and contented life, unity in resolution, spirit, and mind is essential. These lofty ideals of fraternity additionally resonate in the shloka of RigVéda that says, "Move together, talk together, let your minds understand alike. Common be your prayer, common be the acquirement, common be your purpose, associated be the desire. Common be your purpose, common be your hearts(feelings) and common be your mind(thoughts). Let the strength of mutual cooperation be firm in you all." (RigVéda, Mandala-10, Sukta-191, Mantra-4). Maha Upanișad, another paramount Vedic text, utilizes the term 'Vasudhaiva Kutumbakam' meaning 'entire world is one family and only diminutive and narrow-minded people adopt two divergent perspectives towards mundane matters.' The shloka of Maha Upanișad reads as follows, "only diminutive and narrow-minded people adopt two divergent perspectives towards mundane matters and do 'mine and dine'; but for those who are broad-minded and have higher consciousness, the whole world is one's own family" (Maha Upanișad, Chapter 6, Verse 72).

\section{-Justice}

According to Article 10 of the Universal Declaration of Human Rights, "everyone has the right, in absolute equality, to a fair and public hearing before an independent and impartial tribunal in the determination of his rights and obligations and of any criminal charge against him." One can sense this sentiment of UDHR resonat- 
ing in Vedic literature to some extent. The study of Vedic literature reveals that India had some kind of legal structure in place even during the Vedic period.Law as a matter of divine prescriptions and philosophic debate has an impressive history in India. During the Vedic period, dharma was considered to be a special attribute of man and a man bereft of dharma was considered identically tantamount to an animal. The Védas are considered as the 'first source of dharma' ( Rama-2004). The Vedic Ruler, as head of the Judiciary, was the guardian and protector of Dharma and to dispense justice was raj-dharma. The King was the holder of the law, but not the source of law and in this process, he was guided by dharma. The King's autonomy was limited by tribal councils known as Sabha and Samiti. The two organisations. The two bodies aided the king in governance and justice administration.The Vedic king represented lord Yama while performing justice. Yama was the deity of justice, dharma, death, and the south direction. According to the Védas, Yama was the first mortal to die, and through implicative insinuation, he became the king of the deceased. There were three sources of Dharma law which availed the king while performing equity. The first source was Védas. The second source was Dharmashastra texts of which consequential ones were Dharma Sūtra of Gautama and Baudhyana, Sūtras of Apastamba, Harita, Vashista, and Visnu. The Dharmastras primarily dealt with civil and criminal law rules.The third source of dharma was called the 'âchâra', which betokens customary law. Âchârs were the norms of a particular community or group. Just like the Smṛti texts, âchâra finds its ascendancy by its connection with the Védas. Where both the Védas and the Dharmaśāstra were silent on any issue, a learned person who was well versed in Védas could consider the norms of the community as dharma and perform it. Thus, it is conspicuous that during the Vedic period, dispensation of justice was one of the most consequential works of the king. According to K.M. Panikkar, the king's coronation ceremony was a Diksha- devoting his life to the cause (accommodation of the people) ( Panikkar-1963). There is an episode of King Mahendra in Vedic texts wherein the king is visually perceived recollecting the knowledge imparted by his father as a guide to dispensing equity in a cow larceny case. Mahendra's father taught him to be impartial when resolving a dispute and to prioritize the pieces of evidence available over anything else.

The foundation of justice established in the Vedic texts was expanded upon in post-Vedic texts such as Nrada Smti, Manu Smti, and Yjavalkya Smti Smti.Nārada Smrti advises the king to appoint only suitable people as judges who are well versed in law and who are noble and impartial. Nārada Smriti says, "Let the king designate as members of the Court of Justice honourable men of tried honesty (sabhyas) who can shoulder the burden of justice administration and who are well versed in sacred laws, rules of prudence, who are virtuous and unbiased towards friends and foes" ( Nārada Smṛti p. 36-4-5). Nārada Smṛti further advises the king to dispense justice by taking decisions unanimously in consultation with all the judges as this would leave no doubt in the minds of litigants. According to Nārada Smrrti, a unanimous decision by the judges leaves no room for doubt, while a majority decision leaves plaintiffs with doubts (Nārada Smṛti, Dharmakosha, p. 48.). The Vedic texts advise the king to refrain from greed and anger and strictly follow dharma ( constitutional law) to dispense justice. The king and judges were further advised to not hear cases when alone and nor 
should they do any hearing clandestinely. The judgment should be free from all types of biases.

-Humane Treatment

Article 23 (3) of the Universal Declaration of Human Rights verbally expresses, "all who works has the right to just and auspicious remuneration sufficient to ensure the survival of respectable human dignity for himself and his family, which must be balanced by other forms of social protection" "(UDHR-1948). The concept of just and humane treatment gets resonance in the hymns of Atharva Véda where the master is directed to take care of the welfare and magnification of people working under him. The hymn verbally expresses; "Take care of the welfare and magnification of all your people. Then you will grow as the sun grows and shines at dawn and after its rise "(Sharma-2004). The Vedic literature authoritatively commands a person not to be indifferent to his wife, auxiliaries, diseases, domestic animals, wealth, erudition, studies, or doing accommodation to gentleman for even a single moment.These things should always be taken care of. A noble person is the one who considers the interests of others to be his own and accomplishes it even at the cost of his loss. (Dwivedi-2009). According to Vedic texts, everyone in the world deserves to be ecstatic and free, and consequently, the king should rule the earth along the right path. The Garuda Purāna exhorts the king to not to be exasperated over his auxiliaries without ample cause. There are two significant hymns in Garuda Purāna which advocate for just and humane treatments towards employees. They read as follows:

"The king who becomes irate with his employees without ample cause genuinely takes in the poison regurgitated by an ebony serpent" (Garuda Purāna-1.111.27).

"It is despicable on his component to fret and fume without faults in others. He who penalizes his employees unjustifiably becomes a victim of the enemies' attack. " ( Garuda Purāṇa-1.111.30).

Besides the above, there are several other hymns in Vedic literature wherein the seers are visually perceived praying for the dignity and self-reverence of individuals.

\section{-Happiness}

Every human being wants to be happy, and all consciously or unconsciously endeavor for it. It is the rudimentary desire of all human beings and many constitutions in the world verbalize the right to happiness. The US Constitution guarantees the right to the pursuit of happiness, not happiness itself, as it is surmised that no one can promise, bestow, or provide happiness when no one has any authority over it. The Vedic texts are plenary of prayers in which the seers are optically discerned asking for the happiness, peace and prosperity of all. There is a prayer in Sanskrit wherein the seers give a call for "Lokah Samastah Sukhino Bhavantu" meaning "Let all the people in the world be happy. Let all the world be happy". There is another popular prayer in Vedic literature that prays for the ecstasy and salubrity of the whole world. This prayer is mentioned in Garuḍa Purāna (35.51). Aśírvacanam (2) of itihāsa samuccaya, and Mantrabhāṣya (Vājasneya Samhitã ) of Uvața. "May all be happy; may all be liberated from infirmities/disease; may all experience good; may no one be suppressed/inundated by grief and suffering," the prayer says.Om peace, peace, peace". This is one of the most beautiful verses that illustrates the concept of universal salubrity.This 
verse is often quoted in the context of ecstasy, spirituality, universality, and salubrity. It is like a tranquility benediction for the macrocosmic welfare. It desires for the welfare of all humans irrespective of caste, creed, sex, etc. Similarly, the Brihadaranyak Upanisashad says, "Guide me from falsehood to truth; guide me from darkness to light; guide me from death to immortality."(Brihadaranyak Upaniṣad (1.3.28). Another text named Taittiriya Upanișad, identifies the highest Reality (God) with Happiness (Ananda), Bliss (Parama-Ananda) and queries (Jigyasa).

\section{-Gender Rights}

Studying the history of the role and status of women within a community is one of the best ways to understand its essence, venerate its value, and acknowledge its limits (Choudhury-2013).During the Vedic period, women relished all privileges equal to men, and both men and women relished fair status in society. According to RigVéda, "The entire macrocosm of noble people bows to the majestic woman's glory in order for her to enlighten us with sagacity and foresight. She is a pillar of society who imparts wisdom to all. She is a symbol of wealth and a famous sibling. May we value her in order for her to eradicate evil and hate from society "(RigVéda, 1.48.8). Women's right to participate in war, gymnastics, archery, horse riding, recreational activities, inculcation, decision-making, and the option of choosing male spouses reflected the core of the role of women in the convivial context of the RigVedic era (Altekar-1938). Women's freedom to participate in war, gymnastics, archery, horse riding, recreational activities, inculcation, decision-making, and the option of choosing male spouses reflected the core of the role of women in the convivial context of the RigVedic era (Altekar-1938).

Vedic women were entitled to Upanayana samskara ${ }^{6}$, which allowed them to wear the sacred thread and be educated by the Vedic mantras. Some of them were brahmavadinis, women who dedicated their lives to the study of the Scriptures, expounded the Védas and indited some of the Vedic hymns. Women of the governing and warrior class also received martial arts coaching and arms training and weapons skills. Examples of female philosophers, rulers, teachers, administrators, and saints can be found in the Védas, Upanișads, and other scriptures. Yajur Véda tells us, "With her intellect, the learned woman purifies our lives. Through her actions, she purifies our conduct. Through her awareness and action, she inspires morality and effective societal management. " (Yajur Véda 20.84). Thus, the Vedic woman was sanctioned to pursue higher education, and the marriageable age was decided only after she had reached puberty. Famous female seers and philosophers included Apala, Ghosa, Lopamudra, Maitreyi, and Indrani, who edited the hymns of Védas.Lopamudra, Agastya Muni's wife, is credited with composing two hymns by igVéda.In the Vedic era, it was compulsory to be with a wife to perform any Vedic rituals and a man without a wife was considered incomplete as only a wife could consummate him in his journey of life for procuring the four aspects of life, Dharma (obligation), Artha (possession), Kama (love and desires) and conclusively Moksha (emancipation). (Borah-2018). The wife (patni) was referred to as ardhangini (better half), sahadharmini (equal partner), and dharmapatni (licit wife). (Pal-2019). The RigVéda proclaims that, "The wife and husband, as equal halves of one material, are equal in every respect; therefore, both should enter and take equal parts in all works, religious and secular." The Upanișads pellucidly state individual souls are neither male 
nor female (Laungani-2015). Similarly, Atharva Véda states that when a woman marries, she is expected to rule the family as a queen, along with her husband (Atharva Véda 14.1.43-44). The husband and wife union was not confined to one life only but extended to seven lives and beyond. The institution of marriage in Vedic society has been elaborately laid down in Vedic texts. Sage Svetketu is credited for introducing the virtuous practice of fidelity in Hindu marriage. According to Mahabhrata-Adi Parva-122, king Pandu lost his procreative power due to a deer's curse.He tries to convince his wife Kunti to raise a progeny from someone else. The story reads, Pandu saying to Kunti, "Now I'm going to tell you about the ancient practices developed by the great Rishis, who were experts in every area of morality. In the past, women were not limited to their homes and relied on husbands and other relatives. They used to go around openly, enjoying themselves as they wished. They didn't have to be obedient to their spouses, and then it wasn't considered a sin. This practice is followed even today by birds and beasts, and rivalry is rarely found among them. This was the tradition of antiquity sanctioned by the great Rishis, and the present practice has come into existence recently. There was a great Rishi called Uddalaka, and his son Shvetaketu was also a great ascetic. The present virtuoso tradition of fidelity between husband and wife was founded by Shvetaketu out of rage. One day, he saw his mother being held by hand by another brahmin and carried away, saying, "Let's go." This brought great rage to Shvetaketu. Uddalaka tried to convince his son to claim that nothing was incorrect, as this is the tradition allowed by antiquity, and women are free to do what they want. Shvetaketu disagreed and established the rule of total and exclusive faithfulness between the husband's wife.Women transgressing the boundaries of marriage and men breaching a woman who follows the vow of virginity would be sinful to the point of bhrunahatya (caused by abortion) "(Mahabhārata Adi Parva Adhyaya-122. Courts of India).

During the Vedic age, the unmarried woman also had the right to property. The married woman could inherit her father's property only when she had no brother. The women were also allowed to re-marry. Therefore, it is conspicuous that the position of women during the RigVedic period was very vigorous and they relished many privileges and freedoms. The Rg-Vedá-Samihita mentions the names of several consequential female deities including Aditi, the goddess of liberation "(trans. Mu“ller 1869, p. 243); Sárasvatī, the" best woman, the best of the rivers, the best of the goddesses "(trans. Griffith 1896, Hymn XLI); Sāvitrī, the mother of the Védas, and associated with the popular Gāyatrī mantra7 (RigVéda 3.62.10); Usha, the goddess of the dawn; Rathri, the goddess of the night; Prithvi, the mother earth; and Vac, the goddess of verbalization. These female deities were worshipped with consummate dedication. . However, during the later Vedic and postVedic periods, the status of a woman deteriorated and many of her privileges, such as the right to land, Upanayana Samskara, etc., were confiscated. . Manu Smrti deprives women of economic privileges, but the same text talks very clearly regarding women in one of its hymns, in which it is stated that the "deities dwell in the place where women are worshipped". (Manu Smriti. 8.3.11)

It is also noteworthy that most Antediluvian Indian lawmakers of the later Vedic and post-Vedic periods did not recognize a woman's right to own immovable property such as land, houses, etc., but they all unanimously acknowledged a woman's right to stridhana (ornaments, 
jewelry, cash, etc. given to her at the time of her marriage or gifts received from her husband, parents, etc.).The woman had a prerogative over stridhana. According to Hindu law, no one can take away the stridhana of a woman, not even her husband.

\section{-Education}

The term "Véda" implicatively insinuates "sacred knowledge". Knowledge is alluded to in the Vedic literature as an essential need and purifying potency. It was believed to be the enlightening and transforming and purifying force on earth (Srimad Bhagavat-Gita, chapter 4. verse 38). According to F. E. Keay, "the Vedic education system was built in such a manner that it managed to survive not only in the events of the crumbling of empires and the changes of society but, also through all those thousands of years, managed to keep a glow of torch of higher learning" (Keay1960). Albeit the Vedic Society verbalizes about the Varna system, i.e. social stratification dependent on occupation such as Brahmins (edifiers and priests), Kshatriya (warriors and rulers), Vaishya (traders and peasants), and Shudras (artisans and laborers) in the 90th hymn "Purusha Sukta" of the 10th Book in the RigVéda, yet the Varna structure was not rigorous, and many philomaths found Purusha Sukta to be a later addition to RigVéda (Nagarajan-1994). Nevertheless, the Dalit bellwether and engenderer of the Indian Constitution, B.R. Ambedkar, did not concur that the Varna structure did not subsist in the Vedic age, but endeavored to point out that the fourth caste, Shudra (considered to be the lowest) was not pristine to the Vedic age, and the Purusha Sukta described above could have been tampered with by Brahmin priests of the latter time (Ambedkar, 1970). Ambedkar has theorized that Shudras pristinely belonged to the Kshatriya community and cites Shanti Parva from Mahabhārata-60.38-40 as the primary piece of evidence (Marbaniang-2015). It is evident that during the Vedic period every one including people from lower Varana had access to education and could become Brahmins after receiving education, for example; seers like Valmiki hailed from lower varna but he became a renowned Brahmin sage and composed the popular epic literature Ramayana, similarly, another seer Ved Vyasa who composed Mahabhārata was also born in lower Varna but became a Brahmin sage after receiving education.

\section{-Property}

The right to own property is no longer just a constitutional or statutory right; it is also a human right.The RigVedic society was rudimentarily pastoral. During the later Vedic period, the pastoral economy turned into an agrarian economy. The king was the owner of the entire land in his kingdom, but simultaneously the owner and the joint family additionally owned it. However, private ownership was inhibited only on agricultural land. During the RigVedic age, the king realized Bali was a voluntary tax. This denotes that no particular consequentiality was integrated into land rights because society was mainly pastoral. The king didn't establish the absolute right over the land owned by his subjects. His ascendancy over the land was inhabited and he was entitled to have a portion (Bhaga) of the produce. According to Atharva Véda(as quoted in Sharma-2004), the King's ascendancy over land was constrained and it is pellucid from one of the hymns of Atharva Véda wherein lord Indra is invoked to give the king's portion (Bhaga) in the village engender. Similarly, Panchavimsa Brahmana verbalizes, the king 
was entitled to accumulate his quota (Bhaga) in the farm's engender as a tax. Further stressing the right to property, Ishopanishad verbally expresses, "enjoy by giving, do not covet others' wealth" (Goyandaka1972). The right to ownership of land developed only during the later and post-Vedic period and it is evident from ManuSmrti which says that the title of land belongs to a person who first cleared the woods.

\section{-Children's Rights}

The Vedic concept of children's rights is profoundly ingrained in the notion of parents' obligation and dharma. The right upbringing of the child was the required obligation of the parents. The children were considered a harbinger of bliss and bliss in the life of the parents. According to Brihadaranyak Upanișad, a person can live a consummating life on earth only by having children (Brihadaranyak Upaniṣad 1.5.17). In the other line of the same verse of Brihadaranyak Upanișad, it is mentioned that parents were obliged to give their children education and enable them to recognize 'Svadharma' (one's prescribed duty in life). Responsibilities to children during the Vedic period can be optically discerned from the fact that a range of Vedic sacraments (called Samskāras in Sanskrit) have to be performed by the parents with full dedication. Life was thought to be celebrated as a reminder that it was a gift from God. Every phase of a person's life is considered to be very sacred and to be celebrated. There were 16 sacraments (Sodaśa Samskāras ) that were to be performed from birth to death. (Pandey2003). Of these 16 sacraments, twelve (12) were to be performed by parents for their children afore their children reach the age of twenty-five (25). This shows that parents were obligated bound to protect their children and ascertain their opportune upbringing. These obligations of parents mentioned in Vedic literature could be interpreted as children's rights.

\section{Conclusion}

The study concludes that Vedic and later Vedic texts which constitute the fulcrum of Sanskrit literature resonate with some important elements of rights. The in-depth study of Vedic and later Vedic literature reveals that the human rights concept was largely present in ancient India with a rider of equal accentuation on performing obligations. The exegesis of Vedic literature reveals the important ideals of innate rights which are akin to contemporary human rights. It is also evident that the concept of human rights could be further reinforced by treating obligations as corollaries of human rights, as mentioned in Vedic texts. The concept of dharma is another remarkable feature mentioned in Vedic texts which can be correlated to the concept of law, equity, rights, and obligations. There are further shlokas in Vedic literature that are relatable to the concept of a right to education, the right to happiness, right to justice, right to property, non-discrimination, child rights, gender rights, and the right to equality.

\section{Notes}

1. The term apaurușeyatva means 'no human beings. In the Appendix of the "RigVéda Samhitã ", the discussion on apauruseyatva, has been reiterated. ABORI 80. 10-13.

2. Mantradrashtas refers to the seers who saw(drashta) the Vedic hymns that were revealed to them by God himself. 
3. Universal Declaration of Human Rights(UDHR: ) at 70: 30 Articles on 30 Articles - Article 29. Retrieved from https://www.ohchr.org/EN/NewsEvents/Pages/DisplayNews.aspx?NewsID=23999\&LangID=E

4. Manu Smriti : The Manu Smriti . IX-31 reads that : Yatha swarin bhutani dhara dharyate samam; tatha swarin bhutani bibharte parthivm vartam Much as the mother earth provides equal support to all living beings, a king should provide equal support to all without discrimination.

5. Nārada Smṛti vide Dharmakosha, P-870 says "Pashandanaigama sreni poogavraata ganadishu, Samrakshet samayam Raja Durge Janapade Tatha" The hymn above means, the king should protect all Vedic believers (Naigamas) and disbelievers in Védas (Pashandis) and others.

6. There were 16 sacraments(Sodaśa Samskāras) that were to be performed from birth to death and Upanayana Samskara was one of them. The sixteen Samskāras were as follows:

i. Garbhadhana (Conception)

This Samskāra was to be performed by the parents when they decide to have a child. It is comprised of fervent prayer to God for blessing the couple in conceiving a good and worthy child. So we see that the duty of parents started from the time when they decide to have a child.

ii. Punsavana (Foetus protection)

This Samskāra was performed during the third or fourth month of pregnancy to protect the fetus in the womb. mother)

iii. Simantonnayana (Satisfying the cravings of the pregnant

This Samskāra was akin to a present-day baby shower ceremony, and was, performed during the seventh month of pregnancy wherein the prayers were offered to God for the health of both mother and child in the womb.

iv. Jatakarma (Childbirth)

Mantras were recited for a healthy and long life of the child at his birth.

v. Namakaran (Naming the child)

The child was given a name.

vi. Nishkramana (Taking the child outdoors for the first time)

This Samskāra was performed in the fourth month after birth when the child was taken out of the house for the first time.

vii. Annaprasana (Giving solid food)

This Saṃskāra was performed in the sixth, seventh, or eighth month child when the child was given solid food for the first time.

viii. Mundan (Hair shaving)

This Samskāra was performed in the first or third year of a child's age when the child's hair was shaved.

ix. Karnavedha (Ear piercing)

This Samskāra was performed in the third or fifth year of the child's age when the child's ear was pierced.

x. Upanayana (Sacred thread ceremony)

This was one of the most important Samıskāra that was performed when the child was introduced to education.

xi. Védarambha (Study of Védas) 
This Saṃskāra was performed either at the time of Upanayana or within one year of Upanayana Samskāra. The child starts learning Védas from his teacher and the first shloka that was taught was the auspicious Gayatri Mantra.

xii. Samavartana (Returning home after completion of education)

This Samskāra was performed to celebrate the returning of the child to home from teacher's ashram after completing his education at the age of about 25 years.

xiii. Vivaha (Marriage ceremony)

xiv. Vanaprastha (Preparation for renunciation)

This Samskāra was performed at the age of 50 when the person started his spiritual journey by renouncing worldly life and proceeding to the forest for spiritual upliftment.

xv. Sannyasa (Renunciation)

This Samskāra was performed after Vanaprastha at the age of 75 when a person starts preparing for salvation.

xvi. Antyesthi (Cremation)

This was the final Samskāra that was performed by a person's descendants after his death..

7. Gayatri mantra: This is one of the most important mantra of RigVéda. The refrain is used in a variety of ceremonial ways. The mantra is

om bhūr bhuvah svah

tat savitur varenyam

bhargo devasya dhimahi

dhiyo yo nah pracodayāt

- Rigvéda 3.62.10

It means, "we revere the excellent greatness of the holy Savitra; may she motivate and inspire our intelligence".

\section{References}

Atharvavéda-Samjnana Sukta. Courts of India, p-24

Atharva Véda 14.1.43-44

Altekar, A.S. (1938). The position of women in Hindu civilization: From prehistoric times to the present day Benares Hindu University Press, India.

Ambedkar, B.R.(1970). Who Were the Shudras? Vol. I . Thackers.

Basham, A.L.(1959). The Wonder that was India. New York: Grove Press Inc. p-88.

Bilimoria, Purushottama. (1993).'Rights and Duties: The (Modern) Indian Dilemma', in: Ninian Smart, Shivesh Thakur (eds.), Ethical and Political Dilemmas of Modern India, New York: St. Martin's Press/Basingstoke: MacMillan 1993, 44-49.

Borah, Liza( May 21, 2018). Philosophy of Hindu Marriage. Pragyata. Retrieved from

Brihadaranyak Upanișad 1.4.14 (Courts of India, p-27)

Brihadaranyak Upanișad 1.3.28 ( Courts of India).

Brihadaranyak Upanișad 1.5.17

Bokil, Prof VP. (2001). Sanskrit and Education Ideas, Souvenir-World Sanskrit Conference, Lai Bahadur Shastri Rashtriya Sanskrit Vidyapeeth, New Delhi.

Carman, John B. (1988). 'Duties and Rights in Hindu Society', in: Leroy S. Rouner (ed.), Human Rights and the World's Religions, Notre Dame, Ind.: University of Notre Dame Press. pp 113-128.

Choudhury, S. (2013), 'Gender Discrimination and Social Exclusion: Assam Experience', IJDS Vol.V, Issue-1.4045

Clayton, AC. (1980). The Riga Véda and Vedic Religion, Bharati Prakashan, Varanasi.

Coward, H. G. (2016). The Encyclopedia of Indian Philosophies, Volume 5: The Philosophy of the Grammarians.

Cox, Larry (2014, April 14). Human Rights Must Get Religion. openDemocracy. Retrieved on 21 May 2020 from https://www.opendemocracy.net/en/openglobalrights-openpage/human-rights-must-get-religion/

Dandekar, R. (2000). VEDIC LITERATURE: A Quick Overview. Annals of the Bhandarkar Oriental Research Institute, 81(1/4), 1-13. Retrieved August 22, 2020, from http://www.jstor.org/stable/41694604

Dwivedi, D. (2009). Thoughts For Human Rights In Vedic Tradition. The Indian Journal of Political Science,70(4), 1021-1034. Retrieved May 2, 2020, from www.jstor.org/stable/42744017 
Eliot, Sir Charles. (2004). Philosophy and Self, East and West, In K. N. Tiwari, Comparative Religion, Delhi, Motilal Banarsidass Publishers, p. 8.

Garuda Purāna 1.111.27

Garuda Purāna1.111.30

Gonthier, Charles D. (2000). Liberty, Equality, Fraternity: The Forgotten Leg of the Trilogy, or Fraternity: The Unspoken Third Pillar of Democracy. MCGILL L.J. 45(3) p.567, 570

Goyandaka, Harikrishna (ed). (1972). Ishopanishad Upanișad, Geeta Press, Gorakhpur, India.

Griffith, R. T. H. (2013). RigVéda. Digireads.com Publishing. (eBook)

Johari, J.C. ( 1989). , Principal of Modern Political Science. Sterling Books. P-190.

Jones T.W.(1975).Master of Political Thought, Vol-2. Oxford University Press, Calcutta, India.

Kumar, Shailendra., Choudhury, Sanghamitra.(2021). Ancient Vedic literature and Human Rights: Resonances and Dissonances. Cogent Social Science. Vol. 7 No. 1.

https://doi.org/10.1080/23311886.2020.1858562

Laungani, Nirmal.(2015). Women's Status in Ancient India. Hinduism Today. Retrieved on 22 May 2020 from https://www.hinduismtoday.com/modules/smartsection/item.php?itemid=5566

Mahabhārata Adi Parva Adhyaya 120. 17. 20. Courts of India, page 28.

Mahabhārata Adi Parva Adhyaya -122. Courts of India.

Mahabhārata (Anusasana Parva 61.32-33). Courts of India.

Mahabhārata -Poona edition xii 57, 41. In Basham, A.L.(1959). The Wonder that was India. New York: Grove Press Inc. p-88.

Maha Upanișad, Chapter 6, Verse 72.

Manu Smriti 8.3.11

Marbaniang, Domenic. (2015). History of Hinduism: Pre-Vedic and Vedic Age. Lulu Press, Inc.

Mencken, H.L.(1942). A New Dictionary of Quotations . Alfred A. Knopf Inc., New York. p.682

Moyn, Samuel. (2016). “Rights vs. Duties: Reclaiming Civic Balance.” Boston Review.

Muller, M. (1869). Rig-Véda - Samhitã , the Sacred Hymns of the Brahmans; together with the Commentary of Sayanacharya. Vol. 1-6. London.

https://scholar.google.com/scholar?q=Védavyasa $\% 201500 \% 20 \mathrm{BCE}-1000 \% 20 \mathrm{BCE} \% 2 \mathrm{C} \% 20 \% \mathrm{E} 1 \% \mathrm{~B} 9 \% 9 \mathrm{Ag}$ -

Ved\%C3\%A1-

Sa\%E1\%B9\%83hit\%C4\%81\%2C\%20The\%20Sacred\%20Hymns\%20of\%20the\%20Br\%C4\%81hma\%E1\%B9\%87as \%20vol.\%201\%2C\%20trans.\%20FM\%20M\%C3\%BCller\%201869\%2C\%20Tr\%C3\%BCbner\%20and\%20Company \%2C \%20London.

Muller, F. M., Shastri, S. N., \& Śunahśepa, . (1968). A history of ancient Sanskrit literature so far as it illustrates the primitive religion of the Brahmans. Varanasi: Chowkhamba Sanskrit Series Office.

Nagarajan, V (1994). Origins of Hindu social system. South Asia Books. pp. 16, 121.

Nanda. (1997) 'Hinduism and Human Rights', in Werner (ed.), Human Rights and Humanitarian Law: The Quest for Universality (The Hague, Boston: M. Nijhoff) 29-31.

Nārada Smṛti vide Dharmakosha, P-870

Nārada Smṛti p. 36-4-5 [Dharmakosha p.43] (Courts of India)

Nārada Smṛti vide Dharmakosha p. 48] [Courts of India p-39]

Pal, B. (2019). The saga of women's status in ancient Indian civilization, Miscellanea Geographica, 23(3), 180-184. doi: https://doi.org/10.2478/mgrsd-2019-0012

Pandeya, R.C. (1986). "Human Rights: An Indian Perspective", in Ricoeur (ed.), UNESCO, Philosophical Foundations of Human Rights (Paris: UNESCO, 1986), p. 267.

Panikkar, K. M. (1963). The ideas of sovereignty and state in Indian political thought. Bombay: Bharatiya Vidya Bhavan.

Patel, Dipti. (2005)."The Religious Foundations of Human Rights: A Perspective from the Judeo-Christian Tradition and Hinduism. Human Rights Law Commentary. Vol. 1. retrieved April-15, 2020 from http://www.nottingham.ac.uk/shared/shared_hrlcpub/HRLC_Commentary_2005/PATE L.pdf

People's Union for Civil Liberties Karnataka (PUCL-K) \& Forum Against Atrocities on Women, Mangalore.( September,2012). Attacking Pubs and Birthday parties- Communal Policing by Hindutva Outfits report. http://puclkarnataka.org/wp-content/uploads/2012/11/Mangalore-Report.pdf

Pandey, Rajbali. (2003). The Hindu Sacraments (Samiskāra) in S. Radhakrishnan (ed.) The Cultural Heritage of India, 2nd Edition, Motilal Banarsidass, ISBN 81-85843-03-1, page 23.

Rama, J. M. (2004). Legal and constitutional history of India: Ancient legal, judicial and constitutional system. Delhi: Universal Law Pub.

Rama, J. M. ( February 11, 2017). Justice Dr. M. Rama Jois speech delivered at Tenth Durga Das Basu Memorial Lecture organized by West Bengal National University on 11 $1^{\text {th }}$ February, 2017. Retrieved on 20 May 2020 from https://nujs.edu/news/10thddbasumemorial-lecture.pdf

RigVéda $8: 38: 12$. 
RigVéda 9.112.01

RigVéda 1.89.1

RigVéda, Mandala-5, Sukta-60, Mantra-5

RigVéda Mandala-10, Sukta-191, Mantra-4

RigVéda 1.48 .8

Rosen, Steven J. (2006). Introduction to The World's Major Religions HINDUISM. Green Wood Press London, 2006, vol.6 p.14

Sen, K. M. (2005). Hinduism, Penguin Books, pp. 14-15.

Setzer, Valdemar. W. (2013). Liberty, Equality, Fraternity: Past, Present, Future." Retrieved on 25 May,2020 from https://www.ime.usp.br/ vwsetzer/liberty-equality-fraternity.html

Sharma, Arvind.(2004). Hinduism and Human Rights: A Conceptual Approach, New Delhi: Oxford University Press 2004. p-14

Sharma,A.K., Talwar, Balvir. ( 2004)Business excellence enshrined in Vedic (Hindu) philosophy. Singaprore Management Review

Sherma, R. D. G., \& Sharma, A. (2008). Hermeneutics and Hindu thought: Toward a fusion of horizons. New York: Springer.

Srimad Bhagvat Gita, Chapter II, Verse 47. Gorakhpur: Gita Press, India.( (2015 edition).

Srimad Bhagavat-Gita, Chapter 4. verse 38. Gorakhpur: Gita Press, India.( (2015 edition).

Tyler, C. (1997). Thomas Hill Green (1836-1882) and the philosophical foundations of politics: An internal critique. Lewiston, N.Y: Edwin Mellen Press.

Tyler, Colin(Summer 2019 Edition). "Thomas Hill Green", The Stanford Encyclopedia of Philosophy . Edward N. Zalta (ed.). retrieved from URL $=<$ https://plato.stanford.edu/archives/sum2019/entries/green/

United Nations ( 1948). Universal Declaration of Human Rights. Retrieved from

https://www.un.org/en/universal-declaration-human-rights/

Yajur Véda 20.84

Winternitz, M.(1975). A history of Indian literature. Delhi- Motilal Banarasidas. Vol. 1. P.3.

Winternitz, M. (1977). Some Problems of Indian Literature. Delhi-Bharatiya Book Corporation 